\title{
Elektrostatik Yüklemenin “First Red” Gül Çeşidinin Depolanması Üzerine Etkisi
}

\author{
Gülnaz YILDIZ ${ }^{1}$, Yüksel AYDOĞAN ${ }^{* 2}$ \\ ${ }^{1}$ Aydın Adnan Menderes Üniversitesi Fen Bilimleri Enstitüsü Tarım Makinaları Anabilim Dalı-Aydın \\ ${ }^{2}$ Aydın Adnan Menderes Üniversitesi, Ziraat Fakültesi, Biyosistem Mühendisliği-Aydın
}

Öz: Bu çalışmada 'First Red' çeşidi gülün, hasat sonrası yaşamsal faaliyetlerini koruma altına almak ve vazo ömrünü uzun tutmak için elektrostatik depolama sistemi kullanılmış ve gül üzerindeki etkileri incelenmiştir. Denemeler için etrafı kapalı bir kabin ve elektrostatik alan oluşturmayı sağlayan transformatör kullanılmıştır. Her bir uygulama için 15 adet First Red çeşidi gül kullanılmışır. Ön deneme olarak değerlendirilen kontrol grubu ile kalibrasyonu yapılan depolama sisteminde, $+70,+140,+210,-70,-140$ ve -210 voltaj statik elektrik yüklerinde yapılan denemeler 0-2-4-6 gün aralıklarında değerlendirilmiştir. Değerlendirmeler sonucunda güllerde meydana gelen ağılık kayıpları, boyun bükme açıları, su tüketim değerleri, yaprak ve taç yapraklardaki renk değişimleri, etilen ve karbondioksit miktarları ile nem değerlerine ilişkin veriler incelenmiş ve istatiksel olarak analizleri yapılmıştır. Elde edilen sonuçlara göre, ağırlık kaybı 6 . günün sonunda $+210 \mathrm{~V}$ elektrostatik uygulama ile $31.98 \mathrm{~g}$ olarak en iyi değeri vermiştir. Boyun bükülmesi, 6. günün sonunda en az $-210 \mathrm{~V}$ elektrostatik uygulama ile $6.86^{\circ}$ değerinde gerçekleşmiştir. Su tüketimi, 6 . gün sonunda en iyi değerlerin $-70 \mathrm{~V},-140 \mathrm{~V}$ ve $+140 \mathrm{~V}$ yüklerinde gerçekleştiği tespit edilmiştir. Taç ve çanak yapraklarındaki değişimler, $-210 \mathrm{~V}$ elektrik yükünde olumlu sonuçları vermiştir. Etilen miktarı -210 V statik elektrik yükü ile koruma altına alınmış ve 6 . günün sonunda 16 ppm değerine indirilmesi sağlanmıştır. Karbondioksit miktarı ile nem değerlerinde değişiklik görülmemiştir.

Anahtar kelimeler: Çiçek, hasat sonrası, elektrik, dayanım süresi

\section{Effects of Electrostatic Charging on Storage of "First Red" Rose}

\begin{abstract}
In this study, the electrostatic storage system was used to protect the life of the 'First Red' cultivar after the harvest and to keep the vase life long, and its effects on the rose were investigated. A enclosed enclosure and a transformer to create an electrostatic field were used for the trials. 15 pieces of First Red rose were used for each application. In the storage system calibrated with the control group evaluated as a preliminary trial, the experiments carried out in static electricity loads of $+70,+140,+210,-70,-140$ and -210 voltage were evaluated between 0-2-4-6 days. As a result of the evaluations, the data regarding the weight losses, neck bending angles, water consumption values, color changes in leaves and petals, ethylene and carbon dioxide amounts and moisture values were examined and statistically analyzed. According to the results obtained, the weight loss gave the best value as $31.98 \mathrm{~g}$ with $+210 \mathrm{~V}$ electrostatic application at the end of the 6th day. Neck bending was realized at $6.86^{\circ}$ with at least -210 V electrostatic application at the end of the 6 th day. Water consumption, at the end of the 6 th day, the best values were determined to be at $-70 \mathrm{~V},-140 \mathrm{~V}$ and $+140 \mathrm{~V}$ charge. Changes in the crown and sepals gave positive results at $-210 \mathrm{~V}$ electrical charge. The amount of ethylene was protected with a static electricity charge of -210 $\mathrm{V}$ and it was reduced to 16 ppm at the end of the 6th day. There was no change in the amount of carbon dioxide and humidity.
\end{abstract}

Keywords: Flower, postharvest, electricity, endurance period

\section{GiRiş}

Kokusu ve canlı renkleri ile toplumda etkin bir değere sahip olan güller, duyguların en güzelini ve en büyüğünü sözlerden sonra dile getirilmesinde büyük rol oynamaktadır. Özel günlerde en çok tercih edilen ve diğer kesme çiçeklere göre fiyatı 2-3 kat artış gösteren güllerin, ekonomik değerinde sürekli olarak artış sağlanmaktadır. İnsanların duygularını renkleriyle anlatırken bukette tek sayılarda bulunması duyguların yoğunluğunu ve bir kişiye ait olduğunu da göstermektedir (Demircioğlu, 2010).

Gül (Rosa sp.) Rosaceae familyasından 1-2 m arasında uzayabilen, bol saçak köke sahip, yarı odunsu, çok yıllık çalı formunda bir bitkidir. Güllerin gövde ve dalları dikenlidir. Dallardan çıkan yapraklar 5-7-9 parçadan oluşur. Çiçekler 5 petalli taç yapraklı, erkek organları sarı başlı olup gonca içinde grup halinde bulunur. Bugün farklı renklerde yetiştirilen gül çeşitleri Rosa gallica, Rosa indica ve Rosa lutea olmak üzere üç ana gül üzerinde yapılan melezleme çalışmaları ile yüzlerce yeni kültür formu elde edilmiştir (Tuna, 2012).

Türkiye coğrafi konumundan dolayı pazar ülkelere yakın olması ve sahip olduğu ekolojik özellikleri ile kesme çiçek üretiminde gelişme kaydetmektedir. Türkiye, dünya kesme çiçek ticaretinde söz sahibi birçok ülkeye göre henüz gelişme aşamasındadır. Ekonomik anlamda kesme çiçek yetiştiriciliği, küçümsenmeyecek düzeyde olmasına karşın; arzu edilen üretim miktarına ve kalite düzeyine henüz ulaşılamamıştır. Bunun sebebi ise üretimden nakliye ve pazarlanmasına kadar geçen süreç içerisinde gerekli

*Sorumlu Yazar: yuksel@adu.edu.tr Bu çalışma yüksek lisans tez ürünüdür ve Aydın Adnan Menderes

Üniversitesi Bilimsel Araştırma Projeleri Koordinasyon Birimi tarafından desteklenmiştir (Proje No: ZRF-19006)

Geliş Tarihi: 9 Temmuz 2020

Kabul Tarihi: 10 Mart 2021 
teşkilatlanmanın sağlanamaması, üretimde kullanılacak olan teknolojinin yetersiz olması ve üretimde tek bir çeşide bağı kalınması başlıca sorunları oluşturarak sektörde istenen seviyeye ulaşmamızı engellemektedir.

Türkiye'de kesme çiçek üretimi; iklim özellikleri, üretim teknolojisi ve satış özellikleri yönünden iç ve dış pazara yönelik üretim olmak üzere iki grupta incelenmektedir. İç pazara yönelik üretim Ege ve Marmara Bölgesi'nde dış pazara yönelik üretim ise Akdeniz Bölgesi'nde yoğunlaşmaktadır. Türkiye genelinde en fazla karanfil, glayöl, gül ve nergis üretimi yapılmaktadır (Taşçığlu ve Sayın, 2005).

Kesme çiçeklerde solunum aktivitesinin hasattan sonra da devam etmesi yapısal bozulmaların nedeni olarak gösterilmektedir. Solunum işleminin devam etmesi; mikroorganizma faaliyetlerinin artan sıcaklığa bağlı olarak hızlanmasına, enzimlerin bozulmasına ve çiçeğin bünyesinde etilen oluşumunu artırarak biyolojik bozulmalara neden olmaktadır. Hasattan sonra meydana gelen bozulmanın engellenmesi için kesme çiçeklerin hızlı ve etkin bir şekilde soğutulması gerekmektedir. Özellikle hızlı bozulan ürünlerin hasat edildikten sonra sıcaklığının 24 saat içerisinde depolama sıcaklığına indirilerek soğutulması, ürünün satış ve depolama kalitesini koruma altına almaktadır. Bunun için yapılması gereken ön soğutma işlemidir. Ön soğutma işlemi ile üründe bulunan gizli ısı alınmaktadır. Ön soğutma işlemi, hava, su ve vakum uygulamaları ile yapılabilmektedir. Yapılan araştırmalara göre, kesme güle $4{ }^{\circ} \mathrm{C}^{\prime}$ de durağan hava ile ön soğutma yapılmış ve $25^{\circ} \mathrm{C}^{\prime}$ deki kontrol grubuna göre vazo ömründe 6 günlük bir artış gözlenmiştir. First Red gül çeşidinde ise 4 ${ }^{\circ} \mathrm{C}$ 'de 24 saat boyunca durağan hava ve buzlu suyla püskürtme yapılarak ön soğutmaya tabii tutulmuştur. Kullanılan her iki yöntemde de kalite parametreleri kontrol altına alınmış olup vazo ömrü üzerinde olumlu sonuçları tespit edilmiştir (Alibaş ve Köksal, 2018).

Kesme çiçekler üzerine yapılan birtakım araştırmalar çiçeklerin yüksek sıcaklıklarda suda taşınmasının faydalı olduğunu, düşük sıcaklıklarda ise buna gerek duyulmadığı belirtilmiştir (Kazaz, 2015).

Ülkemiz deniz taşımacılığında pazar ülkelere yakın olmasından dolayı büyük avantaja sahiptir. Karadeniz, Akdeniz ve Ege denizine sınır bulunan pazar ülkelerine gemiyle ulaşım sağlanarak en ekonomik nakliye gerçekleştirilmektedir. Kesme çiçek ihracatında yaşanan yüksek taşıma maliyetinin önüne deniz yolu taşımacılığı ile geçilebilmektedir. Süs bitkileri ihracatında, hava yolu taşımacılığına alternatif olarak deniz taşımacılığı geliştirilmelidir (Çelikel, 2013).

Kesme çiçeklerde vazo ömrü ve kalite parametrelerinin koruma altına alınması ürünün hem ekonomik değerini hem de satıla bilirliğini artırmak için önem arz etmektedir. Ticari değeri yüksek kaliteli ürünler elde edebilmek için hasat öncesi üretim koşullarının ve kültürel işlemlerin en uygun koşullarda yapılması gerekir. Kesme çiçekleri korumaya yönelik yapılacak çalışmalar ile kalite parametreleri korunma altına alınarak tüketici memnuniyeti sağlanmış olacak ve ülke ekonomisine sağladığı katkı artacaktır (Tuna, 2012).

Wang ve ark. (2005) yapmış oldukları çalışmada yüksek voltajlı elektrostatik alanların çileklerin hasat sonrası kalitesi üzerindeki etkisi incelenmiştir. Çilek meyvesi, solunum hızı, et sıkılığını, çözünür katı içerik poligalakturonaz (pg) faaliyet ve karboksimetalselülaz (Cx-Selülaz) etkinliği $50 \mathrm{kV} / \mathrm{m}$ ve $100 \mathrm{kV} / \mathrm{m}$ yüksek gerilim statik elektrik alanı (HVEF) etkilerini araştırmak için deneysel malzemesi olarak kullanılmıştır. Ortaya çıkan sonuçlarda, solunum oranının önemli ölçüde azaldığını, çözünür katıların içeriğinin yüksek seviyede tutulduğunu ve meyve sertliği yavaş yavaş azalırken poligalaktüronaz ve cx-selüloz aktivitelerinin azaldığı belirtilmiştir. Depolamanın yedinci gününde, HVEF ile muamele edilmiş çürük çilek oranı \%5, kontrol grubu ise \%15'lik kısmı oluşturmaktadır.

Wang ve ark. (2007) yapmış oldukları çalışmada yüksek voltajlı elektrostatik alan (HVEF) oluşturarak, hasat sonrası domateslerin kalitesini koruyabileceğini ileri süren bir çalışma yapmışlardır. Yeşil olgun domatesler, $20{ }^{\circ} \mathrm{C}$ de 2 saat boyunca negatif veya pozitif yüksek elektrostatik alana bırakılmış ve daha sonra 30 gün boyunca $13 \pm 1{ }^{\circ} \mathrm{C}$ de, $\% 85$ 90 oranlarındaki bağıl nemde depolanmıştır. Elde edilen sonuçlar, negatif yüksek elektrostatik alanın $\left(-2 \mathrm{kV} . \mathrm{cm}^{-1}\right)$ sıkışmadaki düşüşü ve renk değişimini, toplam çözünebilir şekeri ve domates meyvesinin titre edilebilir asitliğini depolama sırasında geciktirebileceğini göstermiştir. Depolama sırasında domates meyvesinin solunum ve etilen üretimi, sırasıyla 3 ve 6 gün boyunca negatif yüksek elektrostatik alan etkisiyle geciktirilmiştir. Domates meyvelerinde malondialdehit içeriği ve elektrik iletkenliği artışları, depolama sırasında negatif yüksek elektrostatik alan etkisi ile önemli ölçüde inhibe edilmiştir.

Liu ve ark. (2017) yılında yapmış oldukları çalışmada HVEF'in hurma yetiştiriciliğinde potansiyel bir hasat sonrası teknolojisi olarak etkilerini araştırmışlardır. $600 \mathrm{kV} / \mathrm{m}$ elektrik alan kuvveti kullanılan ve meyveleri 15 gün boyunca saklamadan önce farklı sürelerde $(0,30,60,90$ ve 120 dakika) işlemden geçirilmiştir. Sonuçlar, HVEF'in kilo kaybı oranını 1.0-3.4 kat azaltabildiğini gösterirken, sadece HVEF'in doku bozulmasını geciktirme işleminde başarılı olmadığını ve aynı zamanda etkinin uygulama süresi ile arttığını göstermiştir. HVEF, kilo kaybını geciktirebilir, sertlik oranını ve karbondioksit verimini azaltır. HVEF, malondialdehit (MDA) üretim hızını yaklaşık 1.46-11.22 kat 
baskılayabilir ve HVEF Pektin esteraz aktivitesini inhibe edebilir ve toplam fenolleri değiştirmediği sonucuna ulaşılmıştır.

Dan ve ark. (2018) yapmış oldukları çalışmada Zaoyan Şeftalisinin yüksek voltajlı elektrostatik alanda (HVEF) ağırlık kaybetme hızı, esmerleşme indeksi, çürüme oranı, posa sertliği, solunum aktivitesi ve nispi iletkenliği üzerindeki etkisini incelemişlerdir. Sonuçlar HVEF'in açıkça kilo verme oranını, esmerleşme indeksini ve çürüme oranını azaltabileceğini göstermiştir. Bu arada, solunum aktivitesi ve şeftalinin posa sertliğinin azalması HVEF tarafından kontrol edilmiştir. Şeftalinin HVEF altındaki göreceli iletkenliği yavaş yavaş yükselmiş, bu da şeftalinin olgunluğunu ve yaşlanmasını kontrol edebileceğini belirtmiştir.

Yifan ve Honghui (2011) yapmış oldukları çalışmada yüksek voltajlı elektrostatik alan altında kivi meyvesinin hasat sonrası depolama ömrünü uzun tutmak ve tazeliğini korumaya yönelik çalışmışlardır. Hasat sonrası kivi meyvesi $175 \mathrm{kV} / \mathrm{m}$ tekdüze yüksek voltajlı elektrostatik alanla işlenmiş, 17-30 gün sonra kivi meyvesinin fizyolojik ve biyokimyasal etkileri analiz edilmiştir. Kontrol grubu ile karşılaştırıldığında, sonuç kivi meyvesinin biyolojik enziminin ve etileninin geciktiğini ve olgunlaşma ile yaşlanmasının ertelendiğini kanıtlamıştır. Kivi meyvesi, uygun parametreler seçilerek yüksek verimlilik ve enerji tasarrufu ile taze tutulmuştur.

$\mathrm{Bu}$ çalışmanın amacı, kış ve ilkbahar olmak üzere iki farklı dönemde kesimi yapılan ve önemli bir ticari bir değere sahip olan güllerin, hasattan sonra kalite kriterlerini koruma altına almak ve vazo ömrünü uzun tutmak için geliştirilen farklı statik elektrik yüklerine karşı gösterdiği yapısal değişimler ve bu değişimlerin depolama kriterlerine karşı etkilerinin araştırılması amaçlanmıştır.

\section{MATERYAL VE YÖNTEM}

\section{Materyal}

Rosecea familyasından olan güllerin, dalları dikenli bir yapıda olup, yaprakların uç kısımları sivri ve kenarları tırtıklıdır. 5 petalli olup, her bir petal 2 loba bölünmüştür. Petallerin altında 5 sepal denilen çanak yaprağı bulunmaktadır. Denemeler süresince 'First Red' gül çeşidi üzerinde çalışılmış ve her bir uygulama için 15 adet gül kullanılmıştır. Üreticiden temin edilen güllerin her biri ayrı ayrı numaralandırılmış olup, $12-13 \mathrm{~cm}$ aralıklarında boylama işlemi yapılmıştır.

Elektrostatik depolama sisteminde + ve - yüklerin elde edilebilmesi için ayarlanabilir transformatör kullanılmıştır. Transformatör 0-220 V arasında $1 \mathrm{~V}$ hassasiyete sahip, panelinde açma ve kapama şalteri, emniyet amaçlı sigorta, dijital voltmetre ve ampermetreden oluşmaktadır. Elektrostatik yükleme sistemi ve çalışmada kullanılan materyal Şekil 1'de verilmiştir.

\section{Yöntem}

Elektrostatik depolama sistemi içerisinde değerlendirilmeye alınan güller, dış çevreden etkilenmeyecek şekilde her yönü ile izolasyonu yapılmış, PVC malzemeden imal edilmiş olan kabin içerisine yerleştirilmiştir. Kabin içerisinin net olarak görülmesini sağlayan pleksiglas şeffaf camlar $5 \mathrm{~mm}$ kalınlığında olup kabinin yan çerçevelerine konumlandırılmıştır. Elektrostatik yüksek voltajlı ünite aracılı̆̆ ile kabin içerine gönderilen elektrik yüklerinin elektrostatik alan oluşturabilmesi için, paslanmaya ve oksitlenmeye karşı dirençli, 750 × 520 × 2 mm ebatlarında elektrik iletkenliğine sahip krom çelik plakalar kabinin alt ve üst bölmelerine yerleştirilmiştir. Sistemi oluşturan ünitelerin devre şeması Şekil 2'de yer almaktadır (Aydoğan, 2013).

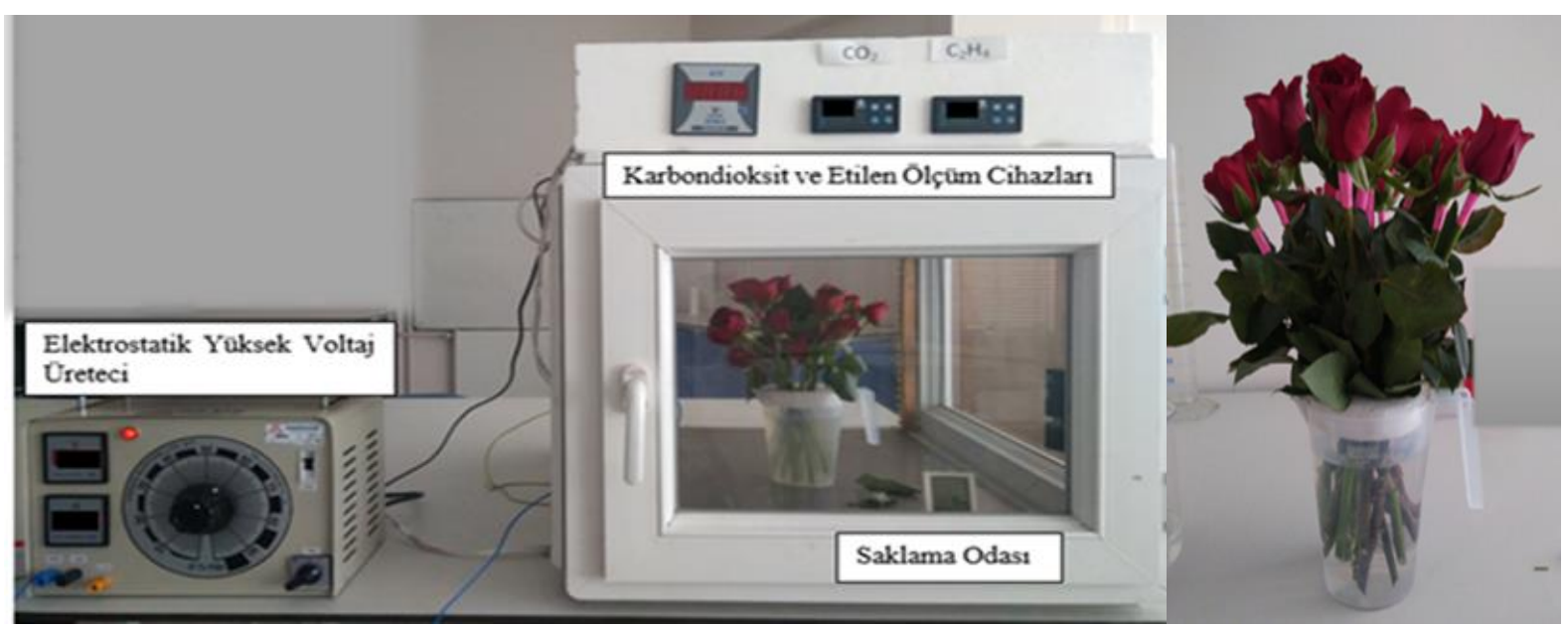

Şekil 1. Elektrostatik yükleme sistemi ve kullanılan materyal 


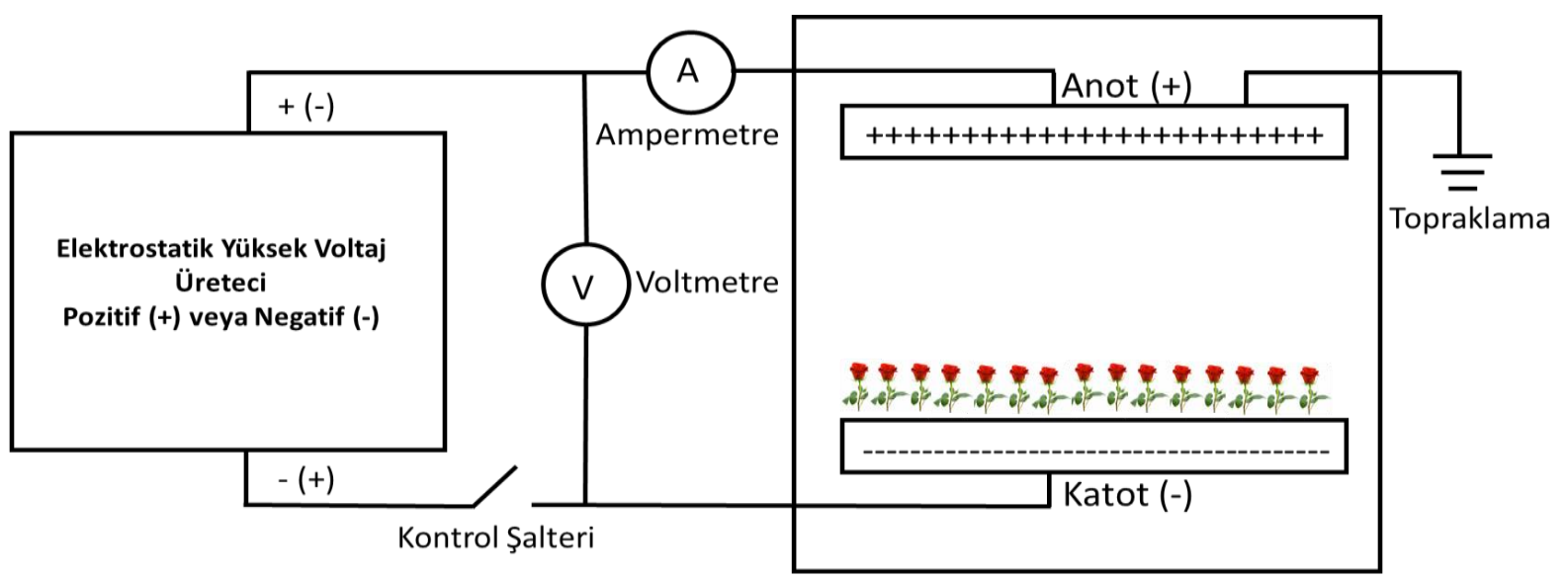

Şekil 2. Elektrostatik yükleme sistemi (Aydoğan, 2013)

Denemeler süresince 0-2-4 ve 6. gün periyotlarında ağırık kayıpları, boyun bükme açıları, su tüketim değerleri, renk değişimleri, karbondioksit ve etilen değerleri ile nem değerlerindeki değişimler incelenmeye alınmıştır.

Denemelerde elektrostatik alan oluşturulmadan önce 15 adet gül normal oda koşullarında $20{ }^{\circ} \mathrm{C}$ sıcaklıkta 0-2-4-6 günleri içerisinde incelenerek kontrol grubunu oluşturmuşlar ve bu süre içerisinde ağırlık kayıpları, boyun bükme açıları, su seviyesi ve renk değişim değerleri incelenmiştir. Daha sonra elektrostatik depolama sistemi içerisinde yer alan güller üzerine $(+)$ ve $(-)$ yükler gönderilerek, $-70,-140,-210,+70,+140,+210$ voltajlarında 0-2-4-6 günlük periyotlarda $20{ }^{\circ} \mathrm{C}$ sıcaklıkta uygulamaları yapılmışırır.

Ağırlık değişimlerini belirleyebilmek için ilk olarak ortalama 12-13 cm aralığında boylama işlemi yapılmış daha sonra rastgele seçilen güller numaralandırılarak ilk ağırlıkları $0.1 \mathrm{gr}$ hassasiyetindeki terazi ile ölçülmüştür. Başlangıç ağırlıkları ile son gündeki ağırlık kayıpları belirlenerek aşağıda yer alan formül ile hesaplanmıştır (Koyuncu, 1999).

\% Ağırlık Kaybı $=\frac{\text { Başlangıç Ağırlığı-Son Ağırlık }}{\text { Başlangıç Ağıllı̆ı }} \times 100$ (1)

Hasat sonrası boyun bükme genellikle çiçeğin yeterli suyu çekememesinden kaynaklanmaktadır (Kazaz, 2015). Kesme güllerde boyun bükme açısının belirlenebilmesi için güller üzerinde bir nokta belirlenmiş ve açıölçer yardımı ile bükülme derecesi ölçülmüştür.

Su tüketim değerlerinin belirlenebilmesi için güllerin sığabileceği şekilde $1000 \mathrm{ml}$ hacme sahip plastik kap kullanılmıştır. İlk olarak 1000 ml'lik sudan belirlenen gün periyotlarında ne kadar azalma olduğunu, güller kapta iken ve güller analiz edildikten sonraki azalma veya artış miktarına göre incelenmiştir.

Renk ölçümü, renk ölçüm cihazı ile yapılmıştır. Cihaz öncelikle siyah ve beyaz plakalar ile kalibre edilerek ölçüme 10 hazır hale getirilmiştir. Her bir gülden alınan yaprak ve taç yaprak numunelerinin renk değişimleri $L, a, b$ değerleri ile ölçülmüştür. Güllerden alınan her bir yaprak ve taç yaprağın renk ölçümleri için 3 farklı değer saptanarak ortalama değerleri alınmış ve $L, a, b$ değerleri okunmuştur. $L$ değeri açıkığı veya koyuluğu, +a yönü kırmızı, -a yönü yeşili, +b yönü ise sarı, -b yönü ise maviye doğru olan renk geçişlerini ifade etmektedir.

Kabin içine yerleştirilen etilen $\left(\mathrm{C}_{2} \mathrm{H}_{4}\right)$ ve karbondioksit $\left(\mathrm{CO}_{2}\right)$ sensörleri ile ortamda oluşan değerler algılanarak dijital ekrana aktarılmış ve anlık olarak değerlerin okunması sağlanmıştır. Kabin içindeki nem değerinin ölçümü doğrudan dijital nem ölçüm cihazı ile \% olarak verilmiştir. Kabin içindeki nem değerleri 0 . gün, 2. gün, 4. gün, 6. gün sonlarında cihaz üzerinden doğrudan okunarak kaydedilmiştir.

Denemeler 3 tekerrür olarak yapılmış olup, ulaşılan veriler Excel ve SPSS istatistik programlarından yararlanılarak her bir uygulama için ayrı ayrı değerlendirilmiştir. Excel programında elde edilen verilerin ortalama değerleri alınarak SPSS programından faydalanılarak One Way Anova analiz yöntemi kullanımıştır. Veriler ANOVA'da analiz edilerek uygulamalar arasındaki farklıık 0.05 önem seviyesinde Tukey testi ile saptanmıştır.

\section{BULGULAR VE TARTIŞMA}

\section{Ağırık kayıplarının değerlendirilmesi}

Ağırlık kaybı için elde edilen sonuçlar incelendiğinde; elektrostatik alanın etkisinde kalan güllerin 6 . gün sonunda gösterdiği en az ağılık kaybı $+210 \mathrm{~V}$ statik elektrik yükü ile $31.98 \mathrm{~g}$ değerinde olduğu ve en fazla ağırlık kaybının ise +70 $\mathrm{V}$ elektrostatik uygulamasında $14.05 \mathrm{~g}$ değerinde olduğu görülmüştür. Diğer elektrostatik uygulamaların kontrol grubuna göre daha az ağırlık kaybı olduğu belirlenmiştir.

\section{Boyun bükme açısının değerlendirilmesi}

Kesme güllerde en sık karşılaşılan sorunlardan biri çiçeğin baş kısmının bir yöne doğru bükülmesidir. Baş kısmının 
bükülmesi ile beliren noktada şişkinlik ve yassı bir görünüm oluşurken çanak yaprağın deformasyona uğramasına da neden olduğu bilinmektedir. (Kazaz, 2015). Su içerisinde bekletilen güllerin, iletim demetinde gelişen fiziksel ve mikrobik tıkanmalar çiçeğin ömrünü ciddi ölçüde etkilemektedir.

Boyun bükme açı değerlerine ait sonuçlar ele alındığında, 6 . gün sonunda en fazla $20.93^{\circ}$ değeri ile kontrol grubunda, en az bükülme ile kalite düşüşünün önüne geçen uygulama ise 6. günün sonunda $-210 \mathrm{~V}$ statik elektrik yüklemesinde $6.86^{\circ}$ değeri olmuştur.

\section{Su tüketiminin değerlendirilmesi}

Kontrol grubu ve elektrostatik alan etkisinde kalan güllerde su tüketimini belirleyebilmek için 1000 ml'lik içi su dolu plastik bir kaba her deneme için 15 adet gül yerleştirilmiştir. Uygulamalar sonucu belirlenen günlerde (0-2-4-6) ölçülü kap yardımı ile su tüketim değerleri ölçülmüştür.

Su tüketimine ait veriler incelendiğinde 6 . günün sonunda, en fazla su tüketimi kontrol grubunda $70 \mathrm{ml}$, en az tüketim ise sırası ile $-70 \mathrm{~V},-140 \mathrm{~V}$ ve $+140 \mathrm{~V}$ elektrostatik uygulamalarında $10 \mathrm{ml}$ değerinde gerçekleşmiştir.

\section{Renk değişim değerleri}

Güllerde renk değişimleri için yaprak ve taç yapraklardan alınan numuneler numaralandırımış paketlere yerleştirilmiştir. Daha sonra renk ölçüm cihazı aracılığı ile ölçümler yapılmıştır.

\section{Yaprak renk değişim değerleri}

Siyah ve beyaz plakalar ile kalibre edilen cihazda renk değerlerini veren $L, a, b$ verileri alınmıştır. $L$ değeri açıklığı veya koyuluğu, +a yönü kırmızı, -a yönü yeşili, +b yönü ise sarı, -b yönü ise maviye doğru olan renk geçişlerini ifade etmektedir.

Yeşil yapraklara ait renk değerlerine ilişkin elde edilen sonuçlara göre, parlaklığı ve canlılığı ifade eden $L$ renk değerlerinden kontrol grubunun 6 . gününde 11.68 değerinde ciddi bir renk kaybı görülürken, $-210 \mathrm{~V}$ elektrostatik yükü ile 33.59 değeri canlılığını en fazla koruyan grup olmuştur.

Yeşil rengi ifade eden negatif a renk değerlerine ait sonuçlar incelendiğinde, 6. gün sonunda en yüksek $-210 \mathrm{~V}$ statik elektrik uygulaması ile -6.53 değeri görülürken, kontrol grubunda -1.16 değerinde gerçekleşmiştir. Pozitif yönü ile değerlendirilen $b$ renk değerlerinde ise 6 . gün sonunda, en yüksek -210 V elektrostatik uygulaması ile 12.14 değerine ulaşılırken, en düşük değer ise kontrol grubunda 5.69 değerinde görülmüştür.

\section{Taç yaprak değişim değerleri}

Güllerden alınan taç yapraklara ait renk değişimleri için $L, a$, b renk değerleri incelenmiştir. Parlaklığı ve canlılığı ifade eden $L$ değerlerinin farklı ortamlardaki durumu değerlendirilmiştir. Taç yapraklardaki en iyi durumu ifade eden sonuç, 6 . günün sonunda $+210 \mathrm{~V}$ statik elektrik uygulaması ile 31.21 değerinde en yüksek sonucu vermiştir.
YILDIZ G, AYDOĞAN Y

En düşük değer ise $70 \mathrm{~V}$ statik elektrik uygulamasında 23.9 değeri olmuştur.

First red gülünün kırmızı rengini ifade eden pozitif a değerleri için elde edilen verilere göre, 6 . günün sonunda en yüksek değer -210 V elektrostatik uygulaması ile 42.7 değerinde görülürken, en düşük değer ise $+70 \mathrm{~V}$ statik elektrik yüklemesi ile 20.15 değerlerinde görülmüştür. +70 V elektrostatik uygulaması ile hızlı bir renk değişimi görülmüş ve taç yapraklarda renk kaybı yaşanarak, solma ve kararma meydana gelmiştir.

Taç yapraklarda sararma durumunu ifade eden b renk değerleri için alınan sonuçlara göre, 6 . günün sonunda en az renk değişimi göstererek en yüksek değere sahip $-210 \mathrm{~V}$ statik elektrik uygulamasında 18.75 değeri olmuştur. En fazla renk kaybı ile en düşük değere sahip olan uygulama ise kontrol grubunun 6 . gününde 8.15 değerinde gerçekleşmiştir.

Kabin içindeki etilen $\left(\mathrm{C}_{2} \mathrm{H}_{4}\right)$ ve karbondioksit $\left(\mathrm{CO}_{2}\right)$ değerleri

Etilen kesme çiçeklerde kontrol altına alınması gereken önemli bir faktördür. Kesme çiçeklerde, yaprak ve taç yaprak dökülmesine, yaprak sararmasına, solma ve yaşlanmaya neden olarak çiçek ve bitki ömrünü kısaltmaktadır (Çelikel, 2013).

Etilen, bitkilerde olgunlaşma sürecinin devam ettiğini ve bu süreç içerisinde hızla artış göstererek bitki ömrünün kısalmasına neden olan önemli faktördür. First Red gülünün elektrostatik depolama sisteminde oluşan etilen verileri incelendiğinde, 6. günün sonunda en düşük etilen miktarı $210 \mathrm{~V}$ yükü ile 16 ppm değeri olmuştur. En fazla etilen üretimi ise $+210 \mathrm{~V}$ elektrik yükünde 81 ppm'e ulaşmış ve yaşlanma süreleri hız kazanarak ciddi kayıplar yaşanmıştır.

Kesme gülde karbondioksit miktarı solunum hızıyla orantılıdır. Solunum hızı ise sıcaklık artışı ile hız kazanmakta ve vazo ömrünün kısalmasına neden olmaktadır. Elektrostatik depolama koşullarında meydana gelen karbondioksit miktarındaki değişimler incelendiğinde 6 . gün sonunda, uygulamalar arasında benzer durumlar yaşanmış ve hemen hemen aynı değerlere ulaşılmıştır. 6. gün sonunda en az $\mathrm{CO}_{2}$ değeri $+210 \mathrm{~V}$ statik elektrik yüklemesi ile 718 ppm değerinde gerçekleşmiştir.

\section{Kabin içindeki nem değerleri}

Kabin içerisine içi su dolu ölçekli plastik kapla yerleştirilen güller su çekebildiği sürece hayatta kalmaktadır. Su çekimi ile yaşamsal faaliyetlerini gösteren güller solunum yaptıkça kapalı ortamda oluşturdukları nem miktarında bir atış sağlanacaktır. Düşük nemli ortamda tutulan çiçeklerde transpirasyon artmakta, bu da su alımı ve taşınımını olumsuz yönde etkileyerek dayanıklılık süresini azaltmaktadır. Veriler genel olarak incelendiğinde kabin içerinde nem durumu stabil tutulmuştur. Uygulamaların ortalamaları alınarak hesaplanan nem değişim değerlerinden en az nem miktarı +210 V elektrostatik 
yüklemesinde ortalama \%83 değerine ulaşmış ve diğer günlerde durum benzer şekilde ilerlemiştir.

Sıcaklığın uygun olduğu koşullarda, solunum hızı yavaşlatmakta ve bitki ömrü uzamaktadır. Kabin içerisindeki sıcaklığın en düşük seviyede tutulması bitkisel ömrü uzatmakta ve ürünün uzak mesafelere taşınmasına olanak sağlamaktadır (Çelikel, 2013). Elektrostatik depolama kabini içerisindeki sıcaklık, genel olarak oda koşullarındaki sıcaklığı sağlayarak $20{ }^{\circ} \mathrm{C}$ olarak gösterilmiştir. Elektrostatik kabin içerisinde ve dışında değerlendirilen güllerden ilk olarak incelenen ağırlık kaybı değerlerinden en az kayıp +210 V statik elektrik yükü ile 31.98 g değerinde olduğu görülürken, en fazla ağırlık kaybı $70 \mathrm{~V}$ elektrostatik uygulamasının 14.05 $\mathrm{g}$ değerinde meydana gelmiştir. Bu uygulamayı takip eden kontrol grubunda ise en fazla çiçek kaybı yaşanan grup olmuştur. Kontrol grubu içerisinde değerlendirmeye alınan 15 adet gülden, deneme sonunda 10 adedi yaşamsal faaliyetlerini yitirmiştir. Diğer statik elektrik yüklemelerinde ise birbirine yakın değerler elde edilmiş ve ağılık kaybını önleyici etkileri ortaya konulmuştur.

Çalışmanın ikinci aşamasında ise boyun bükme açı değerleri incelenmiştir. Yapılan incelemeler sonucunda, kontrol grubunda 20.93 derecelik bir artış ile en fazla boyun bükülmesinin olduğu görülmüş ve bazı güllerde bükülme sonucu gonca ile sapın birleştiği kısımlarda çürüme ve kopma meydana gelmiştir. En az boyun bükülmesi ile kalite düşüşünün önüne geçen uygulama ise $-210 \mathrm{~V}$ statik elektrik yüklemesi ile $6.86^{\circ}$ değeri olmuştur. Yaşamsal faaliyetlerinin devam etmesini sağlayan su tüketim miktarı incelendiğinde kontrol grubunda $70 \mathrm{ml}$ 'lik bir emilimle en fazla seviyeye ulaşmıştır. En az su tüketimini sağlayan gruplar ise $-70 \mathrm{~V}$, $140 \mathrm{~V}, 140 \mathrm{~V}$ ve $-210 \mathrm{~V}$ statik elektrik uygulaması ile istenen bir emilim sağlanmış ve canlılık faaliyetleri korunmuştur.

Güllerin dallarından alınan yapraklarda renk değişimleri için $L, a, \quad b$ değerleri incelenmiştir. Parlaklığı ifade eden $L$ değerleri için kontrol grubunda 11.68 değerinde düşüş yaşanırken, elektrostatik depolama sisteminde $-210 \mathrm{~V}$ yüklemenin etkisi ile 33.59 değerinde en iyi sonuç alınmış ve canlılığın korunduğu bir uygulama olmuştur. Yeşil rengi ifade eden -a renk değerinden, en fazla renk değişimi -1.16 değeri ile kontrol grubunda görülmüş ve yapraklarda lekelenmeler meydana gelmiştir. En az renk değişimi gösteren grup ise $-210 \mathrm{~V}$ statik elektrik uygulamasında -6.53 değeri ile yeşil rengini koruyan grup olarak yer almıştır. Yapraklarda sararma sonucu meydana gelen renk değişimleri $+b$ değeri ile ifade edilmektedir. Yapraklardan elde edilen veriler sonucunda en fazla sararmanın kontrol grubunda 5.59 değerinde olduğu, en az değişimin ise $-210 \mathrm{~V}$ elektrik yükünde 12.45 değerinde olduğu görülmüştür. Genel olarak -210 V elektrostatik uygulamasından olumlu sonuçlar alınmıştır.
Taç yapraklardan alınan örneklerin renk değişimleri için $L, a$, $b$ değerleri incelenmiştir. $L$ değeri için $+210 \mathrm{~V}$ statik elektrik uygulamasında canlılığını koruduğu ve 31.21 değeri ile en yüksek değere ulaştığı görülürken, en düşük sonuç ise $+70 \mathrm{~V}$ elektrostatik uygulamasında 23.9 değerinde elde edilmiştir. +a değeri taç yapraklarda görülen kırmızı rengini ifade etmektedir. +a renk değeri için ulaşılan sonuçlarda, en yüksek değer -210 V elektrostatik uygulaması ile 42.7 değerinde olduğu, en düşük değer kaybı ise $+70 \mathrm{~V}$ elektrostatik uygulamasında 20.15 değerinde gerçekleşmiştir. b değerindeki değişimler incelendiğinde, en az renk değişimi ile en yüksek değere sahip olan $-210 \mathrm{~V}$ statik elektrik yüklemesinde 18.75 değerinde olduğu, en fazla değişim ise kontrol grubunda 8.15 değerinde olduğu görülmüştür. Taç yapraklardan elde edilen sonuçlara göre en iyi-210 V elektrostatik uygulamasından olumlu sonuçlar alınmıştır.

En az etilen üretimi $-210 \mathrm{~V}$ elektrostatik uygulamasında 16 ppm olarak elde edilmiştir. En fazla etilen üretilen uygulama ise $+210 \mathrm{~V}$ elektrostatik uygulamasında $81 \mathrm{ppm}$ değerinde görülmüştür. Karbondioksit miktarı en az +210 V elektrostatik uygulamasında 718 ppm değerinde görülürken, diğer uygulamalara ait sonuçlar aynı şekilde ilerlemiş ve kabin içerisindeki karbondioksit miktarı 720 ppm değerinde görülmüştür. Kabin içindeki nem değerlerinden, en az nem miktarı +210 V elektrostatik yüklemesinde ortalama $\% 83$ değerinde görülürken diğer günlerde durum benzer şekilde ilerlemiş ve \%85.5 değerinde seyretmiştir.

\section{SONUÇ}

Bir döngü içerisinde yer alan güllerin hasat sonrası kalite korumasında etkili olarak sıcaklık belli bir seviyede tutulmalıdır. Sıcaklık artışı ile solunum faaliyeti hız kazanacak ve su çekimi daha fazla olup terleme oranı artacaktır. Bu da solunum faaliyetinin artışı ile meydana gelen etilen miktarının hızla çoğalmasına ve vazo ömrünün hızla azalarak yaşlanmasına ve çiçeğin ölmesine sebep olacaktır.

Elektrostatik depolama sistemine baktığımızda ise yukarıda saymış olduğumuz parametreler kontrol altına alınmaya çalışılmış ve genel olarak elde edilen sonuçlarda $\quad-210 \mathrm{~V}$ ve +140 V statik elektrik yüklemelerinin daha olumlu yönde etkilediği görülmüştür. Bu tip uygulamalar ile ticari değeri ile yüksek hassasiyete sahip olan ürünler değer kaybına uğramadan tüketiciye ulaşma imkanına sahip olabilir. Piyasada ürünün fazla olduğu zamanlarda hasadı gerçekleştirilen güllerin, depolama sistemlerindeki gelişmeler sonucunda depolanma aşamasında meydana gelen deformasyonların kontrol altına alınması mümkün olduğu takdirde yıl içerisinde istenilen zamanlarda kalite kaybı yaşanmadan ürünlerin temin edilmesi kolaylaşacaktır. Farklı elektrostatik yüklemelerin hangi parametreler 
üzerinde daha etkili olduğunu belirtmek için hazırlanmış olan çizelgede en iyi ve en kötü sonuçları veren uygulama şeklinde değerlendirmeleri yapılmıştır (Çizelge 1).

\section{TEŞEKKÜR}

$\mathrm{Bu}$ çalışmanın yürütülmesinde, Aydın Adnan Menderes Üniversitesi Bilimsel Araştırma Projeleri (BAP) birimi (ZRF19006 nolu proje) tarafından verilen destek için teşekkür ederiz.

Çizelge 1. Farklı elektrostatik yüklemelerin parametreler üzerindeki değerlendirmeleri

\begin{tabular}{lcccc}
\hline Ölçülen Parametreler & \multicolumn{2}{c}{ En iyi Uygulama } & \multicolumn{2}{c}{ En Kötü Uygulama } \\
\hline Ağırlık Kaybı & $210 \mathrm{~V}$ & $-210 \mathrm{~V}$ & Kontrol & Kontrol \\
Boyun Bükme Açısı & $-210 \mathrm{~V}$ & $140 \mathrm{~V}$ & Kontrol & $70 \mathrm{~V}$ \\
Su Tüketimi & $-70 \mathrm{~V}$ & $-140 \mathrm{~V}$ & Kontrol & $70 \mathrm{~V}$ \\
Yaprak L & $-210 \mathrm{~V}$ & $140 \mathrm{~V}$ & Kontrol & $70 \mathrm{~V}$ \\
Yaprak a & $-210 \mathrm{~V}$ & $140 \mathrm{~V}$ & Kontrol & $70 \mathrm{~V}$ \\
Yaprak b & $-210 \mathrm{~V}$ & $140 \mathrm{~V}$ & $70 \mathrm{~V}$ & Kontrol \\
Taç Yaprak L & $210 \mathrm{~V}$ & $-140 \mathrm{~V}$ & $70 \mathrm{~V}$ & Kontrol \\
Taç Yaprak a & $-210 \mathrm{~V}$ & $-140 \mathrm{~V}$ & Kontrol & $-140 \mathrm{~V}$ \\
Taç Yaprak b & $-210 \mathrm{~V}$ & $140 \mathrm{~V}$ & $210 \mathrm{~V}$ & $-140 \mathrm{~V}$
\end{tabular}

$\mathrm{CO}_{2}$ Miktarı

Nem Oranı

Uygulamanın bu parametreler üzerinde sonuçları aynı olmuştur.

\section{KAYNAKLAR}

Alibaş I, Köksal N (2018) Süs Bitkilerinde Ön Soğutma Uygulamalarının Önemi ve Kullanım Olanakları. Türk Tarım Gıda Bilim ve Teknoloji Dergisi, 6(5): 586-595.

Aydoğan Y (2013) Elektrostatik Yüklemenin Eriğin Dayanım ve Depolama Süresine Etkileri. Doktora Tezi, Adnan Menderes Üniversitesi Fen Bilimleri Enstitüsü, Aydın.

Çelikel FG (2013) Süs Bitkilerinin Hasat Sonrası Kaliteleri ve Yeni Teknolojiler. V. Süs Bitkileri Kongresi, 06-09 Mayıs 2013, Yalova, 17-25.

Dan Y, Li L, Ye Q, Zhang G (2018) Effect of High Voltage Electrostatic Field on The Post- Harvest Physiology of "Zaoyan" Peach. Food Science, 26: 260-263.

Demircioğlu H (2010) Kesme Gülde (Rosa Hybrida First Red) Farklı 1-Mcp Dozu Uygulamalarının ve Farklı Depolama Koşullarının Vazo Ömrü Üzerine Etkileri. Yüksek Lisans Tezi, Çukurova Üniversitesi Fen Bilimleri Enstitüsü, Adana.

Kazaz S (2015) Kesme Çiçeklerde Hasat Sonrası Ömrü Etkileyen Faktörler. Türkiye Tohumcular Birliği Dergisi 14: 42-46.

Koyuncu MA, Yıldız K (1999) Önemli Bazı Kayısı Çeşitlerinin Muhafaza Süresi ve Kalitesi Üzerine Değişik Ambalaj ve Malzemelerin Etkisi. Derim 16(3): 109-118.
Liu C, Chen W, Chang C, Li PH, Lu PL, Hsieh C (2017) Effect of High Voltage Electrostatic Field (Hvef) on The Shelf Life of Persimmons (Diospyros Kaki). Food Scince and Technology 75: 236-242.

Taşçıŏlu Y, Sayın C (2005) Türkiye'de Kesme Çiçek Üretim ve İhracat Yapısı. Akdeniz Üniversitesi Ziraat Fakültesi Dergisi 18(3): 343-354.

Tuna S (2012) Kesme Gül ve Gerbera Çiçeklerinin Vazo Ömrünü Artırmak İçin Bazı Uçucu Yağlar ve Ana Bileşenlerinin Kullanım Olanakları. Yüksek Lisans Tezi, Süleyman Demirel Üniversitesi Fen Bilimleri Enstitüsü, Isparta.

Wang J, Li L, Ye Q, Wang L (2005) Effect of High Voltage Electrostatic Fields on Post-Harvest Quality of Strawberry Fruit. Agricultural Sciences in China 294298.

Wang Y, Wang B, Li L (2007) Keeping Quality of Tomato Fruit by High Electrostatic Field Pretreatment During Storage. Journal of The Science of Food and Agriculture, 88 (3): 464-470.

Yifan Z, Honghui R (2011) Effects of High Voltage Electrostatic Field Treatment on Post-Harvest Physiology of Kiwifruit. New Technology of Agricultural Engineering (ICAE) International Conference, 27-29 May 2011, China, 994 - 997. 
